\title{
Correction to: Potential causes and consequences of rapid mitochondrial genome evolution in thermoacidophilic Galdieria (Rhodophyta)
}

Chung Hyun Cho ${ }^{1 \dagger}$, Seung In Park ${ }^{1 \dagger}$, Claudia Ciniglia ${ }^{2}$, Eun Chan Yang ${ }^{3}$, Louis Graf ${ }^{1}$, Debashish Bhattacharya ${ }^{4}$ and Hwan Su Yoon ${ }^{1 *}$

Correction to: BMC Evolutionary Biology 20, 112 (2020)

https://doi.org/10.1186/s12862-020-01677-6

Following publication of the original article [1], the authors identified an error in Fig. 1. and Fig. 4. The correct figures are given below.

The correct figures and captions have been included in this correction, and the original article has been corrected.

\footnotetext{
Author details

'Department of Biological Sciences, Sungkyunkwan University, Suwon 16419, South Korea. ${ }^{2}$ Department of Environmental, Biological and Pharmaceutical Science and Technologies, University of Campania Luigi Vanvitelli, 81100 Caserta, Italy. ${ }^{3}$ Marine Ecosystem Research Center, Korea Institute of Ocean Science and Technology, Busan 49111, South Korea. ${ }^{4}$ Department of Biochemistry and Microbiology, Rutgers University, New Brunswick 08901, USA.
}

Published online: 07 October 2020

\section{Reference}

1. Cho, et al. BMC Evolutionary Biology. 2020;20:112 https://doi.org/10.1186/ s12862-020-01677-6.

\footnotetext{
The original article can be found online at https://doi.org/10.1186/s12862020-01677-6.

* Correspondence: hsyoon2011@skku.edu

${ }^{\dagger}$ Chung Hyun Cho and Seung In Park contributed equally to this work.

'Department of Biological Sciences, Sungkyunkwan University, Suwon 16419, South Korea

Full list of author information is available at the end of the article
}

(C) The Author(s). 2020 Open Access This article is licensed under a Creative Commons Attribution 4.0 International License, which permits use, sharing, adaptation, distribution and reproduction in any medium or format, as long as you give appropriate credit to the original author(s) and the source, provide a link to the Creative Commons licence, and indicate if changes were made. The images or other third party material in this article are included in the article's Creative Commons licence, unless indicated otherwise in a credit line to the material. If material is not included in the article's Creative Commons licence and your intended use is not permitted by statutory regulation or exceeds the permitted use, you will need to obtain permission directly from the copyright holder. To view a copy of this licence, visit http://creativecommons.org/licenses/by/4.0/ The Creative Commons Public Domain Dedication waiver (http://creativecommons.org/publicdomain/zero/1.0/) applies to the data made available in this article, unless otherwise stated in a credit line to the data. 


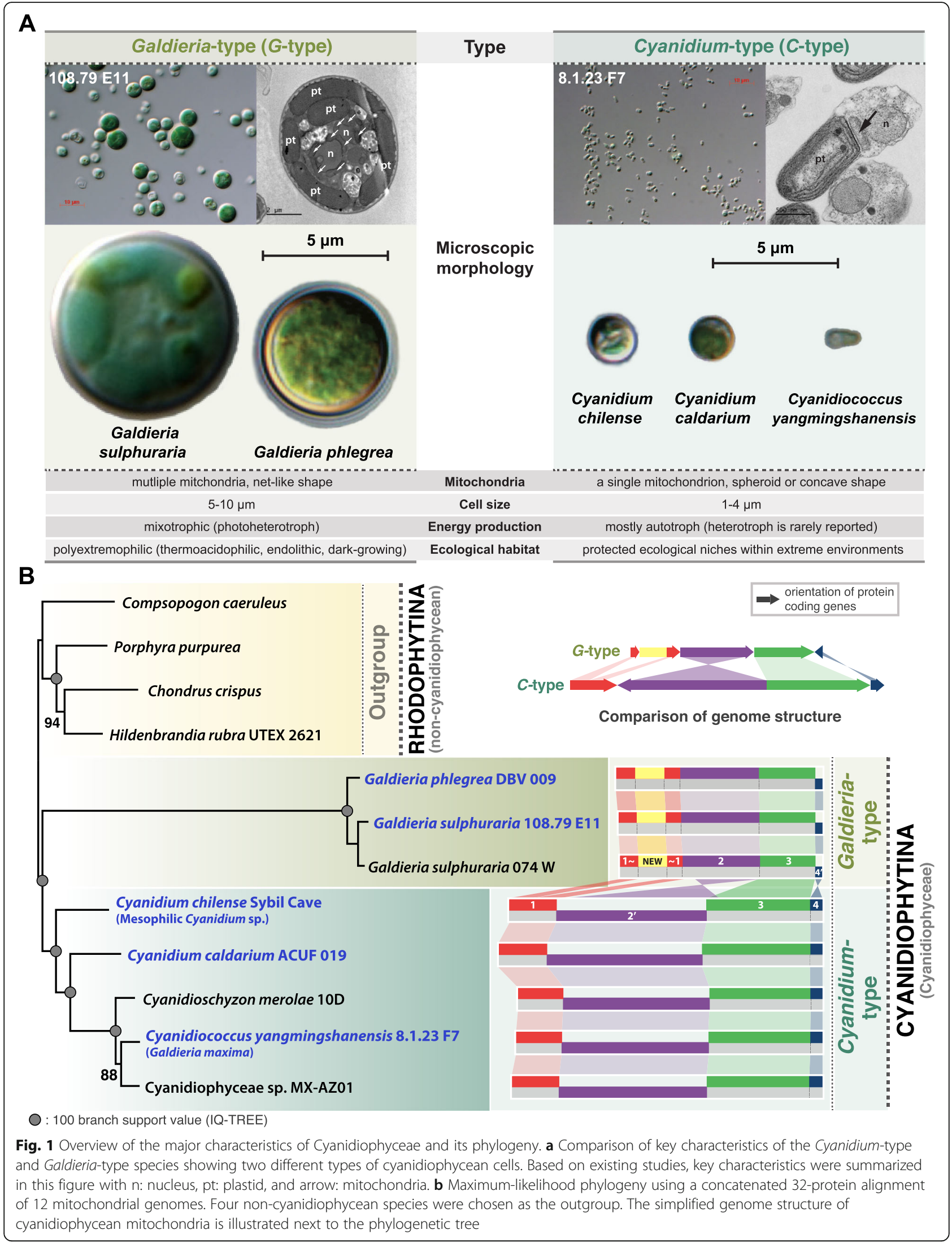




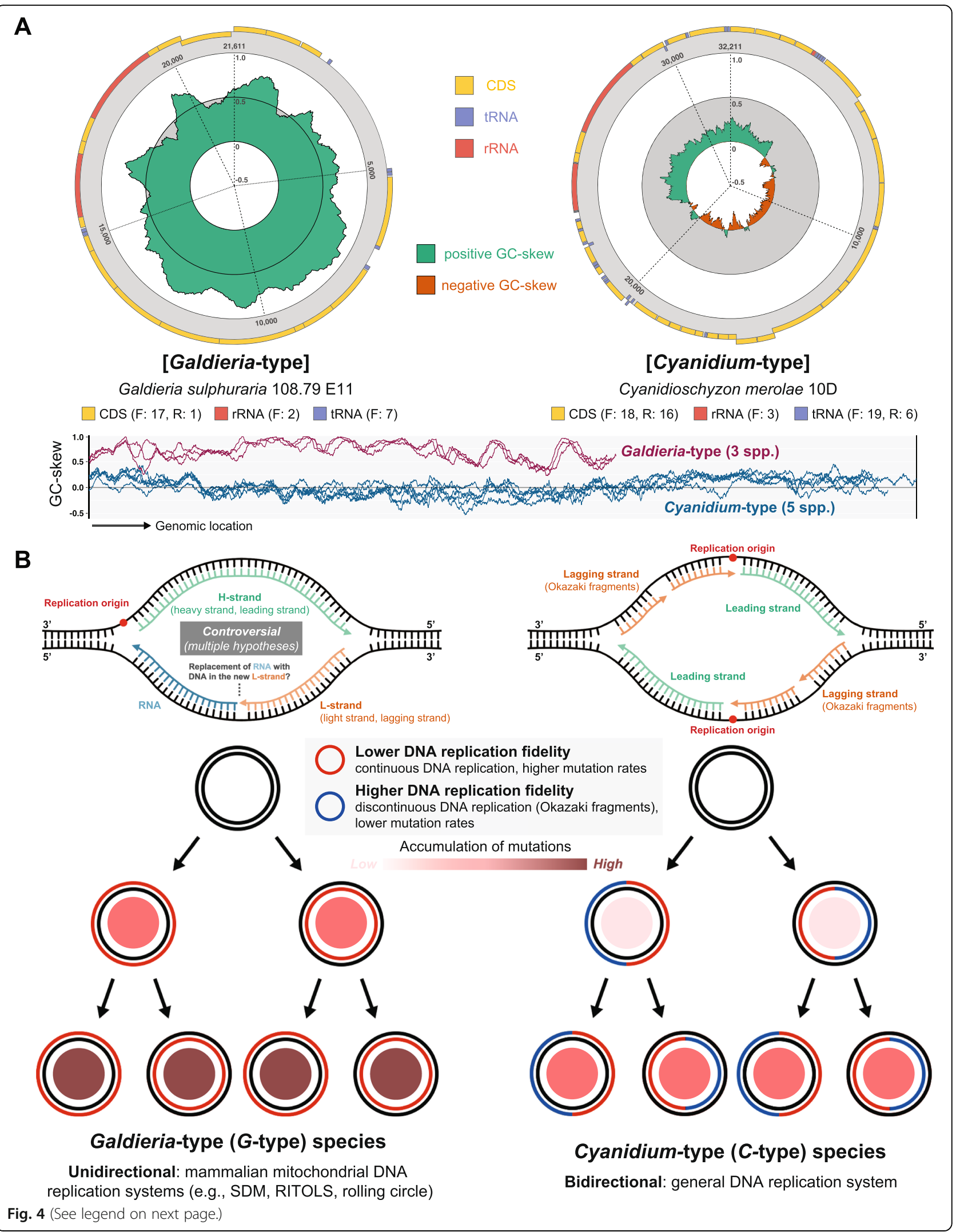


(See figure on previous page.)

Fig. 4 Two different models for mitogenome replication in Cyanidiophyceae. Unidirectional and conservative replication (separate leading and lagging strands for each daughter strand) in Galdieria-type and bidirectional and semiconservative replication (mixed leading and lagging strand for each daughter strand) in Cyanidium-type. a GC-skew of representative structure comparison. F: forward, R: reverse. b Hypothetical models of the mitochondrial DNA replication system and mitogenome inheritance model 